技術報告

\title{
同軸型直線導入機を用いた試料搬送導入装置の開発
}

\author{
小林 英一, ${ }^{1, *}$ 明角 淳志, ${ }^{2}$ 瀬戸山 寛之, ${ }^{1}$ 岡島 敏浩 ${ }^{1}$ \\ ${ }^{1}$ 佐賀県立九州シンクロトロン光研究センター \\ テ841-0005 佐賀県鳥栖市弥生が丘八丁目 7 番地 \\ 2 真空光学株式会社 \\ T146-0092 東京都大田区下丸子2-18-18 \\ kobayashi@saga-ls.jp
}

（2011 年 12 月 31 日受理; 2012 年 6 月 5 日掲載決定）

同軸型直線導入機，真空容器，そして試料格納部から構成されたコンパクトな試料搬送導入装 置を開発した，試料格納部は真空に引いたり，不活性ガスで置換することができ，試料を大気に 曝すことなく分析装置へ移動し分析を行うことができる。試料格納部の到達圧力は〜 4.6× $10^{-4} \mathrm{~Pa}$ であり，20日間もの期間， $1 \times 10^{-3} \mathrm{~Pa}$ 以下に保持可能であることを確認した．本装置にアルゴンス パッタし, 清浄表面を形成したアルミ筞を 41 時間保管した。 その時，表面には〜 $1.0 \mathrm{~nm}$ の酸化膜 が生成された。その酸化膜厚は自然酸化膜の $1 / 4$ 程度であった。

\section{Development of a sample transfer vessel by using a coaxial type linear motion feedthrough}

\author{
E. Kobayashi ${ }^{1,{ }^{*}}$ J. Meikaku, ${ }^{2}$ H. Setoyama, ${ }^{1}$ and T. Okajima ${ }^{1}$ \\ ${ }^{1}$ Kyushu Synchrotron Light Research Center, \\ 8-7 Yayoigaoka, Tosu, Saga 841-0005, Japan \\ ${ }^{2}$ Vacuum and Optical Instruments, \\ 2-18-18 Shimomaruko, Ohta-ku, Tokyo 146-0092, Japan \\ *kobayashi@saga-ls.jp
}

(Received: December 31, 2011; Accepted: June 5, 2012 )

\begin{abstract}
We have developed a compact sample transfer vessel. It consists of coaxial type linear motion feedthrough, vacuum vessel and sample catcher. The sample can be analyzed by using this system without exposing to atmosphere. The vessel pressure reached $\sim 4.6 \times 10^{-4} \mathrm{~Pa}$ and kept $1 \times 10^{-3} \mathrm{~Pa}$ for 20 days. The aluminum on which an argon sputtering was carried out was kept in this equipment for 41 hours. Then, $\sim 1.0 \mathrm{~nm}$ thick oxide film was formed on the surfaces. The oxide film thickness was about $1 / 4$ of the natural oxide layer thickness.
\end{abstract}

1. はじめに

近年, 光電子分光法やオージェ電子分光法は表面 敏感な分析法として広く用いられている.また，国 内の放射光施設の増加に伴い, 軟 X 線吸収分光法や 放射光光電子分光法を用いた研究が多くなってい る.さらに, エネルギー・環境問題の観点から, 軽
元素を含む燃料電池, リチウムイオン二次電池, 水 素吸蔵合金などの研究・開発が盛んになり，これら 材料の表面分析の重要度が増してきている[1].

通常，これらの手法を用いた分析では，試料は大 気中で試料ホルダーに取り付け真空装置にセット 寸る。しかしながら，触媒や電極など表面が活性な 
材料は，大気中の酸素，二酸化炭素，水蒸気などに より污染されてしまう。 そこで, 我々は試料を不活 性ガスで充満させたグローブボックスなどで処理 し, 大気に曝すことなく分析装置へ移動できる同軸 型直線導入機を用いた試料搬送導入機を新たに開 発した[2]. 本装置は, (1)構造が単純で製作や改良及 び修理が容易，(2)製作及び維持コストが低い，(3)汎 用性が高いことなどの特徴を持っている.

\section{2. 試料搬送導入装置の概要と特徵}

試料搬送導入装置の概略図と写真を図 1 に示す. 本装置は同軸型直線導入機と真空容器と試料格納 部から構成され, 全長は $275 \mathrm{~mm}$,重さは約 $1 \mathrm{~kg}$ であ る. 基本形の同軸型直線導入機の移動距離は $40 \mathrm{~mm}$ であるが, 試料ホルダーや取付け装置に応じて移動 距離の長いものに簡単に交換できる.

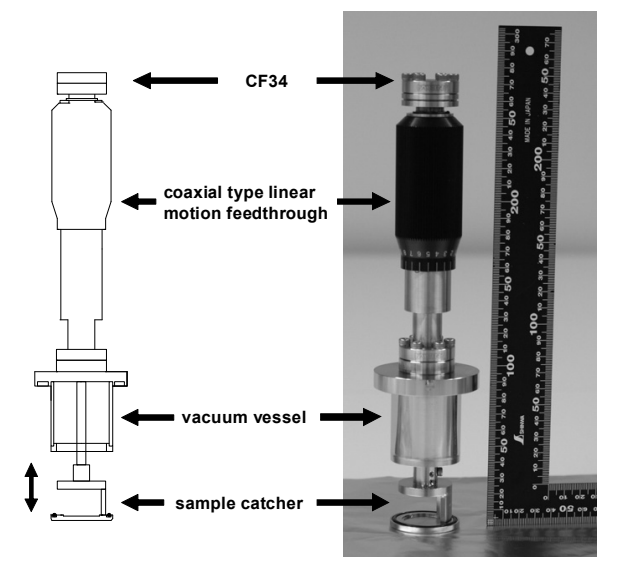

Fig. 1 Cross section and photograph of a sample transfer vessel.

同軸型直線導入機と真空容器は外径 $\phi 34 \mathrm{~mm}$ のコ ンフラットフランジ（以下 CF34 フランジと表記す る）で接続している。これにより，各部品を個別に 製作, 改良や修理して組み立てることが可能となり, 組立て作業の向上とコスト低減が図れる. 試料格納 部は着脱可能で, 試料ホルダーの形状に応じた試料 格納部を準備しておけば，1台の試料搬送導入装置 で各種の試料ホルダーを取り扱うことができる. 加 えて, 複数の試料ホルダーを格納できる試料格納部 を準備しておけば, 複数の試料ホルダーを同時に搬 送して真空装置へ導入できる. 真空容器及び試料格 納部の材質は SUS304 である. 真空容器と試料格納 部のシールはバイトンOリングを使用している.一 方，同軸型直線導入機の反対側も $\mathrm{CF} 34$ となってお り,この部位に予めバルブを取り付けておき, 試料 装着後に真空ポンプを繋ぎ容器内を真空にするこ
とができる.

コンフラットフランジに接続できるように製作し た変換フランジ(図 2)を用いて本装置と分析装置の 予備排気室や試料準備室等の接続を行うことから, 接続先の予備排気室や試料準備室等に特殊ポート を必要としない。この変換フランジのサイズは $\mathrm{CF} 114$ 以上で製作できる. 寸なわち CF114 以上のサ イズの空きポートがあり, 試料搬送導入装置から試 料ホルダーを取出せる空間とそれらを操作できる 機構が備えられていれば, 装置にあった変換フラン ジを準備することでどんな装置にでも接続が可能 である. 試料作製用チャンバーにも同様なポート及 び機構があれば, 作製した試料は大気に曝さずに分 析装置に移動することができる.

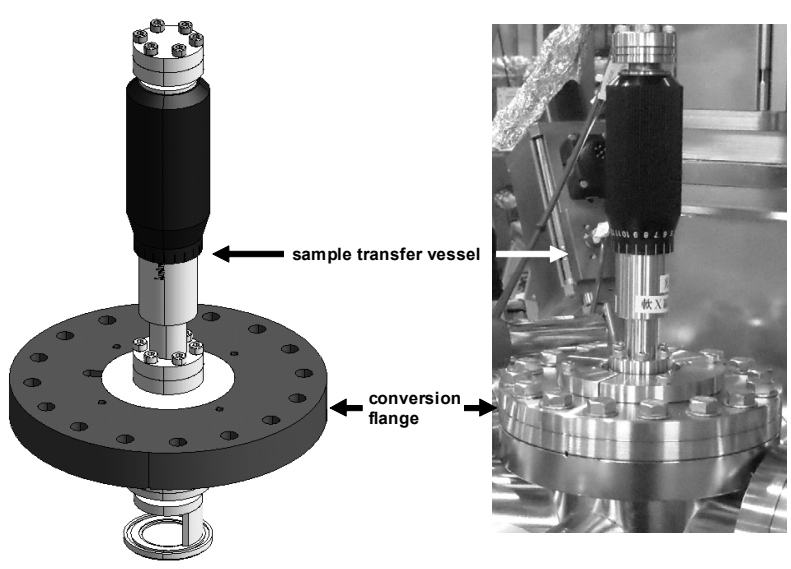

Fig. 2 Schematic diagram and photograph of a conversion flange and a sample transfer vessel.

\section{3. 性能評価}

\section{1 真空特性}

本装置の到達真空度及び真空保持の性能を調べる ために，試料格納部を閉じ，ターボ分子ポンプとス クロールポンプを反対側の CF 34 にベローズシール バルブを介して取り付け，真空引きを行なった．真 空容器内の真空度は CF34 に $\mathrm{T}$ 型の管を取り付け, ピラニ/コールドカソードコンビネーションゲージ を用いて測定した。排気開始から 24 時間までの排 気曲線は図 3 のようになった。 このとき本装置の到 達圧力は $4 \times 10^{-4} \mathrm{~Pa}$ であった。

本装置の最初の目標とする仕様は, 試料を不活性 ガスで充満させたグローブボックス内で処理後, 試 料ホルダーに取付け, 本装置に格納し, 大気に曝す ことなく分析装置へ移動できることである. そのた め, 本測定では装置のベーキング処理を行わなかっ た. また, 同軸型直線導入機の内部のパイプ径が 4 


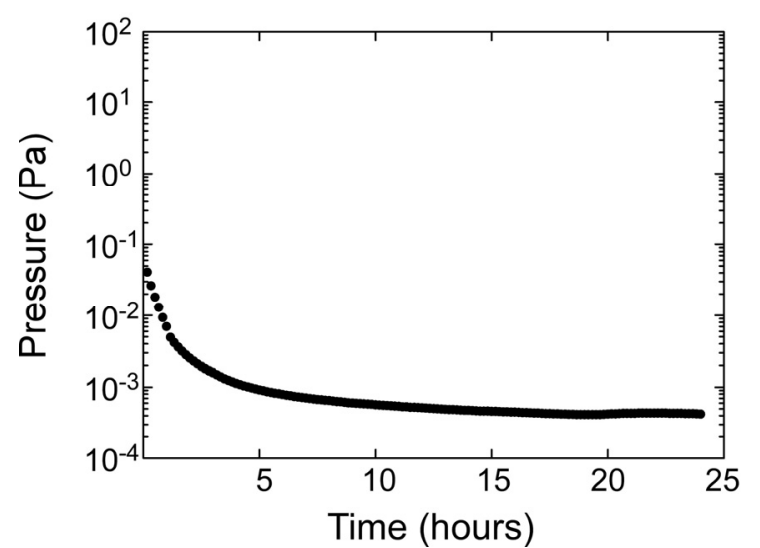

Fig. 3 The exhaust gas vapor pressure curves in a sample transfer vessel.

$\mathrm{mm}$ であり, 今回の評価では真空排気装置との接続 部が 1/4インチサイズのベローズシールバルブを介 して行なっているため真空引きに時間を要した.

ターボ分子ポンプ上流側のベローズシールバル ブを閉じた直後からの圧力と試料搬送導入装置周 辺の気温の時間依存性を図 4 に示す. 真空度はバル ブを閉めた直後，急激に悪くなるが，その後若干の 変動はあるがほぼ一定の真空度を保っている. 真空 保持後の真空度は時間が経つにつれて少しずつ良 くなっている.これらの変化は温度の変化と良く対 応している.さらに，20日間の真空保持において も $1 \times 10^{-3} \mathrm{~Pa}$ 以下の真空度に保たれることを確認し ている.このようなことから本装置による長時間の 真空保持に問題はない. 寸なわち, グローブボック スなどで調整した試料を大気に曝さずに長距離搬 送するには十分であり，放射光実験では，マシンタ イム数日前に各研究室のグローブボックスなどで 調整した試料を放射光施設に持ち込み, 大気に曝さ ずに軟 X線を用いた材料の表面分析が行える.

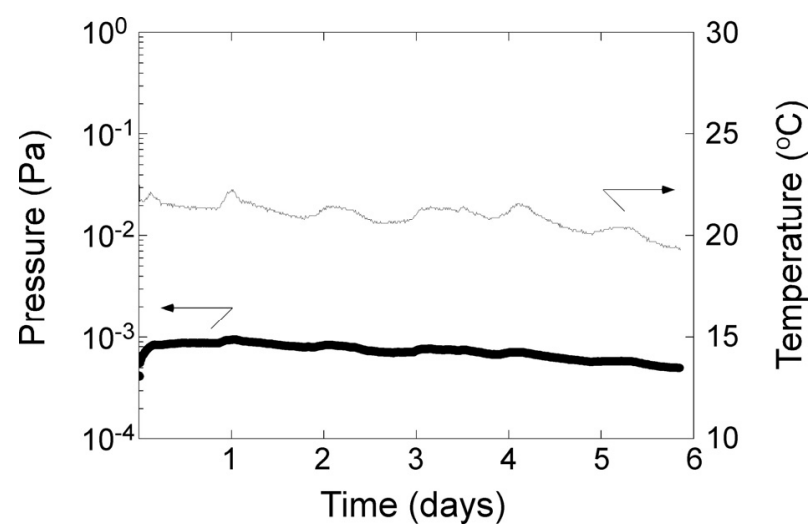

Fig. 4 The relationship between the exhaust gas vapor pressure and the temperature.

\section{2 アルミ箔表面の酸化状態}

アルミは酸化されやすい金属である. 光電子分光 法を用いて, 試料搬送導入装置によるアルミ表面の 酸化抑制効果について調べた。

測定に用いた試料は厚さ $0.1 \mathrm{~mm}$ のアルミ箔（二 ラコ社製， $99 \%$ 以上）を使用した. 光電子スペクト ルの測定は佐賀県立九州シンクロトロン光研究セ ンター（SAGA-LS）の BL12 に設置された ULVAC-PHI 社製の ESCA 1600 （特型）を用いて行 なった. 励起光源に $\mathrm{MgK} \alpha$ 線を使用し, 測定室の真 空度は $2 \times 10^{-7} \mathrm{~Pa}$ 以下であった. アパーチャーサイ ズは $\phi 0.8 \mathrm{~mm}$ である. 電子検出角度は表面法線方向 から 55 度である. エネルギー軸のキャリブレーシ ヨンは, 真空中でイオンスパッタリングした $\mathrm{Au} 4 \mathrm{f}$, $\mathrm{Ag} 3 \mathrm{~d}, \mathrm{Cu} 2 \mathrm{p}$ の光電子スペクトルを測定し, 過去に 報告されているピークの正確な結合エネルギー值 と比較することで行なった. 図 5(a)はアルミ箔試料 を測定室に導入した直後に測定した $\mathrm{Al} 2 \mathrm{p}$ 光電子ス ペクトル，(b)はスパッタ直後の，そして(c) は試料 搬送導入装置で約 41 時間保管した後のスペクトル である. スパッタは加速電圧 $4 \mathrm{kV}$ のアルゴンイオ

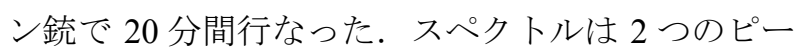
クから成っており, 結合エネルギー〜 $73 \mathrm{eV}$ 付近の ピーク $\mathrm{A}$ は金属成分, $\sim 76 \mathrm{eV}$ 付近のピーク $\mathrm{B}$ は酸 化物成分である[3]. このスペクトルを Shirley 法に よりバックグランドを除去し, 金属成分 A（ピーク 位置 $72.7 \mathrm{eV}$ ） は非対称な成分を含む[4]のでスパッ 夕直後のスペクトル, 酸化物成分 B はガウシアンで フィットし，それぞれのピーク面積を求めた。フィ ットしたカーブは図 5 のスペクトルの下に示した. その結果, アルゴンスパッタする前の試料のピーク 面積の強度比 B/A は 10.0 , 試料搬送導入装置で保管 した場合は 0.8 であった. Strohmeier ら[4]によって 報告された $\mathrm{Al} 2 \mathrm{p}$ 光電子スペクトルの金属と酸化物 成分のピーク面積比と酸化の膜厚との関係式から, ピーク面積の強度比 $\mathrm{B} / \mathrm{A}$ が 10.0 と 0.8 の時の膜厚は それぞれ〜3.7 nm, 1.0 nmであった. 一方, 過去 に奥田ら[5]はアルミの自然酸化膜の厚さを光電子 の検出角度を変える角度分解法を用いて分析し, $3.3 \mathrm{~nm}$ であると報告している. 今回得られたアルゴ ンスパッタをする前の酸化膜の膜厚はこの報告と よく一致している.これらの結果から, 試料搬送導 入装置を用いることでアルミ䇴表面の酸化を $1 / 4$ 程 度に抑制できることがわかった。 
Journal of Surface Analysis Vol. 19 No. 1 (2012) pp. 2-5

\section{小林英一 同軸型直線導入機を用いた試料搬送導入装置の開発}

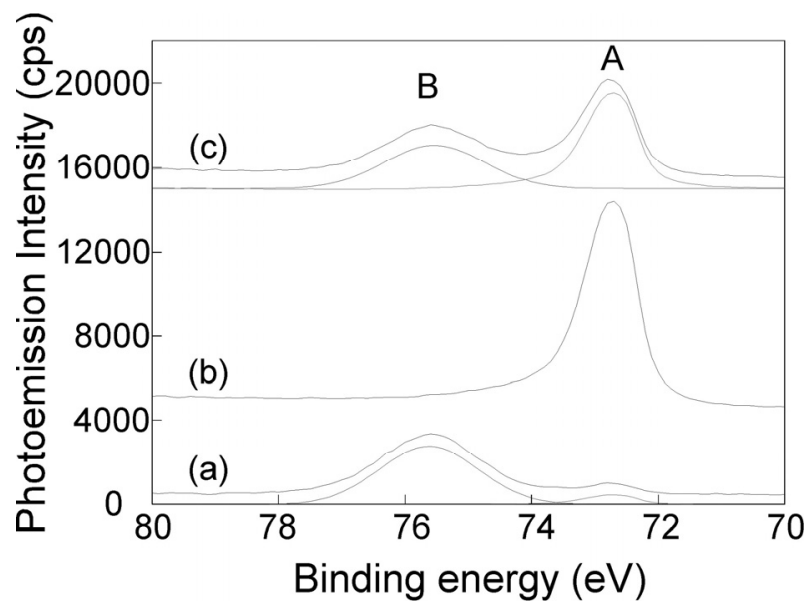

Fig. $5 \mathrm{Al} 2 \mathrm{p}$ photoelectron spectra of $\mathrm{Al}$ foil (a) non treatment, (b) after Ar sputter and (c) keeping by transfer vessel.

\section{4. まとめ}

我々は試料をグローブボックスや真空蒸着装置な どから大気に曝すことなく光電子分光装置などの 真空装置に移動させることができる同軸型直線導 入機を用いた試料搬送導入装置を新たに開発した. 装置は拡張性の高い構造になっており, 様々な試料
ホルダーの形状や様々な表面分析装置, 試料作製装 置への対応が可能である，本装置を用いることで， 試料作製のフレキシビリティが増し，これまで敷居 が高いと敬遠されていた放射光利用への展開への 道筋が開けるものと考えられる.

\section{5. 謝辞}

装置の製作と性能評価用の試料作製に関して議論 してくださった今村元泰氏（産業技術総合研究所） に感謝します。

\section{6. 参考文献}

[1] 小林英一, 岡島敏浩, まてりあ 50, 423 (2011). [2] 小林英一, 明角淳志, 岡島敏浩, 瀬戸山寛之, 公開番号 特開 2010-276369(P2010-276369A).

[3] M.Amstutz and M.Textor, Surf. Interface Anal., 19, 595 (1992).

[4] B. R. Strohmeier, Surf. Interface Anal., 15, 51 (1990). [5] 奥田和明, 伊藤秋男, 分析化学 40, 691 (1991). 